\title{
Market Penetration and Acquisition Strategies for Emerging Economies
}

\author{
Klaus E. Meyer \\ Professor of Business Administration \\ Box 218, University of Reading Business School \\ Whiteknights, Reading, Berkshire, RG6 6AA, UK \\ km.cees@cbs.dk \\ Yen Thi Thu Tran \\ PhD Student \\ Copenhagen Business School \\ Kilevej 14 A, 6., 2000 Frederiksberg, Denmark \\ yttt.ivs@cbs.dk
}

This version: 25 January, 2006

\section{Please refer to the published version of this paper when citing: \\ Meyer, Klaus E. \& Tran, Yen Thi Thu (2006): Market Penetration and Acquisition Strategies \\ for Emerging Economies, Long Range Planning, 39, no. 2, 177-197.}

Acknowledgements: We thank the Social Science Foundation (SSF) Denmark for sponsoring this research as part of the MASEE project (grant number 24-01-0152). We also draw on earlier research sponsored by the Department for International Development (UK) under DFID/ESCOR project no. R7844, Center for New and Emerging Markets, London Business School. We thank our contact persons at Carlsberg A/S and our research partners in Poland, Lithuania and Vietnam for many stimulating discussions, and Bent Pedersen (Copenhagen Business School) and Zeng YuPing (Peking University) for sharing their insights in the Chinese brewing industry. Comments by Arnold Schuh, Mike Peng, Sheila Puffer, Tina Pedersen and Peter Krag as well as conference participants at the $2^{\text {nd }}$ EIASM workshop on 'International Strategy and Cross-Cultural Management' in Edinburgh University, and seminar participants at Copenhagen Business School are gratefully acknowledged. All errors remain the authors’ own responsibility. 


\title{
Market Penetration and Acquisition Strategies for Emerging Economies
}

\begin{abstract}
Multinational enterprises (MNEs) are expanding their global reach, carrying their products and brands to new and diverse markets in emerging economies. As they tailor their strategies to the local context, they have to create product and brand portfolios that match their competences with local needs.

A multi-tier strategy with local and/or global brands may provide MNEs with the widest reach into the market and the potential for market leadership. However, it has to be supported with an appropriate combination of global and local resources. Foreign entrants thus have to develop operational capabilities for the specific context, which requires complementary resources that are typically controlled by local firms. As institutional obstacles and the structural weaknesses of local businesses often inhibit the direct acquisition of such firms, foreign investors may pursue un-conventional strategies, such as staged, multiple, indirect, or Brownfield acquisitions, to acquire local resources.

We outline these strategies for penetrating local markets by acquisition of local firms, and illustrate them with the entry and growth of Carlsberg Breweries in four very different emerging economies: Poland, Lithuania, Vietnam and China.
\end{abstract}




\section{Introduction}

Globalisation brings multinational enterprises (MNEs), their products and their brands into ever more remote corners of the world. The large number of potential customers in emerging economies raises expectations of unprecedented demand for consumer goods, if only the right products could be delivered in the right places. ${ }^{1}$ Yet, MNEs encounter business environments in emerging economies that are not only different from those with which they are familiar, but that also vary greatly from each other.

The main attraction of emerging economies is their high economic growth and the corresponding expectation of rapidly increasing demand for consumer goods. Thus, as C.K. Prahalad argues passionately, there is money to be made "at the bottom of the pyramid”. 2 The sheer number of people with a low income makes even the less developed parts of the world attractive to business. However, these markets pose unique challenges due to their less sophisticated institutional environment and the weak resource endowment of local firms. ${ }^{3}$ Businesses may have to develop different strategies and new business models to serve not only the few wealthy customers in these areas, but also the mass market. ${ }^{4}$

The appropriate positioning of the product portfolio is crucial to success in emerging economies. As Dawar and Chattopadhay ${ }^{5}$ outline, emerging economies comprise very diverse groups of customers that may have to be targeted with different products, brands and even business models. Consequently, potential entrants face tradeoffs between developing a global brand for the premium segment, where substantive margins can be earned, and developing products with large-scale and cost-efficient production for the mass markets and earning profits through volume. International marketing scholars debate the trade-offs of global standardization ${ }^{6}$ and local adaptation ${ }^{7}$ in emerging economies. In addition to global or local brand strategies, many MNEs combine them in a multi-tier strategy that aims to reach both the mass market and the premium segment. We argue that this strategy may be particularly suitable for emerging economies where the large distance between the premium and mass markets is typically big. However, the appropriate strategy depends on the nature of the investor's resources.

Market penetration starts with the entry strategy, which has to provide access to local resources, such as distribution networks and access to local businesses and authorities. In emerging economies, investors have to think beyond the conventional entry modes of Greenfield, acquisition and joint venture (JV). We introduce a more differentiated typology of acquisition strategies that provides better support for 
managerial decisions. In particular, we distinguish between entry modes suitable for foothold strategies, and aggressive ones aimed at market leadership. The creative designing of entry modes, rather than choosing between textbook models, allows MNEs to achieve their objectives in idiosyncratic host environments.

We develop suggestions on how to manage entry in emerging economies by drawing from two research projects on FDI in emerging economies, which are based on local research and interviews at corporate headquarters (see appendix). We illustrate the adaptation of strategies to local contexts by comparing the strategies of one multinational enterprise, Carlsberg Breweries, over the past decade in four emerging economies. This longitudinal and comparative perspective within one MNE allows us to focus on the adaptation to the local contexts. The case shows the finer details of the strategy, and provides a powerful illustration of the issues and the dynamics of strategy evolution that may be overlooked in conventional, large dataset analysis.

The brewing industry provides an interesting case because it has gone through a rapid concentration process over the past decade. Still, even in concentrated markets, local and international brands continue to coexist. The parallel development of multiple brands and the structural changes in the industry reflect trends seen in many other food and beverage industries.

We focus on four countries that reflect the diversity of Carlsberg's experiences. Carlsberg entered Poland with a partial acquisition in 1996, and has built a strong position using staged, multiple, and indirect acquisitions. In Lithuania, Carlsberg took over a local brewery in 1999 and acquired further local brands in a global merger in 2001, thus developing a dominant market position. In Vietnam, Carlsberg entered as early as 1993 with two JVs that serve both the mass market and the local premium market. After long perseverance both generate handsome profits. In China, Carlsberg has been a minor player in the 1990s, but it initiated in 2003 an aggressive strategy of acquisitions in Western China, aiming to capitalize on its emerging economies experience.

We develop our arguments as follows. In the next section, we introduce the emerging economy context. In Section 3, we outline how consumer goods MNEs may position themselves in emerging economies. On this basis, we discuss in Section 4 how MNEs may use acquisitions and joint JVs to access the local resources needed to build their position. Section 5 presents the four case of entry by Carlsberg Breweries, which are set in context in section 6 . Section 7 concludes. 


\section{Opportunities and challenges in emerging markets}

The accelerated entry into emerging economies over the past decade has, in part, been driven by opportunities arising from the sheer size of the markets and their impressive economic growth. Emerging economies offer large markets for consumer goods with a corresponding high growth potential. This applies not only to the special cases of China and India, but also to, for instance, Poland, which is a medium size European market with a population of 38 million. Poland went through a deep recession in the early 1990s followed by spectacular growth throughout the rest of the decade. In contrast, Vietnam has over 80 million people and, in terms of market size, is larger than any European country except Russia. Its per capita income more than quadrupled over the 1990s. Large, fast growing markets and low factor costs make such countries attractive for international businesses.

Despite their attractiveness, emerging economies typically lag behind in terms of economic development and intricacy of the institutional environment. We define emerging economies as economies with high growth or growth potential, but without the sophistication of the institutional framework seen in Western Europe and North America. Foreign entrants face additional obstacles and risks:

- Emerging economies are highly volatile due to frequent changes in institutions, industry structure and the macro-economy. Economic growth may be high, but crises are frequent, as the Asian crisis of 1997 demonstrated. The volatility provides competitive advantage to firms with the strategic flexibility to react to changing circumstances and to grab new business opportunities. ${ }^{8}$

- The institutional frameworks may require different ways of interacting with business partners and authorities. 'Institutional voids' often inhibit the efficiency of markets and increase business risks. ${ }^{9}$ Consequently, firms may internalise markets for intermediate goods and services, such as capital and human capital, ${ }^{10}$ and they may rely to a larger extent on personal relationships to interact with others.

- Many of the capabilities needed to compete in emerging economies are contextspecific. Local firms and individuals develop their capabilities to suit the specific context, which may create major barriers to entry. 
- Many industries are highly fragmented, as many small firms compete for a share of the market. With the entry of foreign investors, the market structure may rapidly change, adding to the uncertainty of the market place.

MNEs have not been deterred by such obstacles, but adapt their strategies. In the next sections, we outline how this can be done, focusing in particular on branding and the acquisition of local resources. Decision makers first need to clarify their long-term objectives, namely their aspired market position. On this basis, they can then analyse which entry mode would be most suitable to achieve their objectives. In this respect, we first discuss long-term marketing strategies before turning to initial entry mode strategies.

\section{Brand Portfolios for Emerging Economy Consumers}

Emerging economies pose different challenges for marketing than industrialised countries. Typically, incomes are low, labour is relatively cheap, and the customer groups are highly variable. However, Dawar and Chattopadhay show that, even under these conditions, foreign investors can profitably serve these markets by adapting their strategies to the local context. For instance, low-income groups can be served by the costefficient production of mass products, emphasising economies of scale and earning profits through high sales volumes. Low incomes constrain demand, but the corresponding low wages also create opportunities for people-intensive approaches to marketing. For instance, sales assistants may hand out samples or promotion materials, or support service in bars and restaurants. Distribution staff may deliver smaller but more frequent shipments to sales outlets.

The variability of customer groups in terms of income and regions challenges MNEs aiming for large market shares because markets may be highly segmented. Principally, foreign entrants could choose between three types of strategy:

1. Global branding strategy - global brand with little or no adaptation, positioned as premium brand,

2. Local branding strategy - portfolio of local brands, positioned to serve mass markets, and

3. Multi-tier branding strategy - portfolio of global local and brands, positioned to serve different segments of the market. 
*** Exhibit 1 approximately here ***

Exhibit 1 illustrates in which contexts these three strategies may be appropriate. These strategic alternatives also exist in industrialized economies, but in emerging economies the segmentation of markets makes the choice of strategy particularly crucial. In emerging economies, one can expect large margin differences between global brands and local mainstream brands. On the one hand, the mass market is highly price sensitive and local competitors may offer standard products at low prices. On the other hand, the premium segment is the prerogative of the middle and upper classes, which are less price sensitive and very status conscious. The suitability of a strategy, and the relative weight given to global and local brands in the product portfolio, varies with the structure of the industry and the firm's own resources and capabilities.

\subsection{Global brands}

A global brand strategy allows focus on the premium segment. This segment is often small, but attractive because of the substantial purchasing power of the middle classes in emerging economies, even where average incomes are low. Volumes are typically small, yet margins in terms of profit per unit sold may be large. The advantages of a global strategy are well recognized. For instance, Quelch points to added value for consumers due to a consistent worldwide brand image, lower costs due to economies of scale, crossborder learning, and attraction and recruitment of ambitious employees. ${ }^{11}$

The premium segment is particularly attractive in cultures where status and prestige are highly valued, as in many Asian countries. One is expected to demonstrate status and prosperity as well as appreciation by offering the best product or brand, when bringing gifts, or when going out with business associates. The prestige of a brand is, therefore, a major factor in the consumers' perceived value of a product. ${ }^{12}$ This phenomenon, known as 'conspicuous consumption', implies that demand for the most expensive brand may exceed that for a less pricey premium brand. Brands thus benefit from being perceived as “The Best”.

A global brand strategy requires, first and foremost, a recognized global brand, along with the ability to communicate the premium brand's values, and to deliver quality under occasionally adverse conditions. ${ }^{13}$ It does not, necessarily require direct investment. Premium brands may be imported and distributed through local agents, especially if the country of origin form part of their image, and transportation costs are low. 


\subsection{Local brands}

A local brand strategy allows serving markets that are in some way distinct from global markets, or that in themselves are highly fragmented. In particular, a portfolio of local brands may not generate huge sales margins, but it can build market share and lower unit costs through economies of scale and volume sales. One cent earned for each of a thousand units is as good as one dollar earned for each of ten units.

Consumer goods, notably durable goods such as washing machines or motorcycles, may be adapted to the needs and purchasing power of emerging economies by reducing the variety of models and by stripping out non-essential product features. At the same time, product features may be adjusted to the needs of emerging markets, such as improving robustness in the presence of unreliable electricity supply and lack of a local service network. Scholars such as Dawar and Chattopadhay point out that such product adjustment may require development costs, but may reach new consumers and increase economies of scale and thus reduce production costs. Others, including London and Hart, ${ }^{14}$ and Prahalad go one step further and advocate the development of new products and business models in a bottom-up fashion through direct interaction with local communities, and by giving local entrepreneurs leverage to adopt products locally.

A portfolio of local products and brands may be particularly suitable where incomes are low on average, or where markets are regionally segmented as a result of high transportation costs (relative to value added), attachment to local brands, the limited reach of media, and people-intensive distribution networks (as in Vietnam).

Success in the mass market requires operational capabilities to support a low cost strategy. In this segment, foreign entrants would compete with local firms that produce at low costs, are familiar with intricacies of the market, well networked and used to flexibly adjust to a volatile economy and to frequent changes in rules and regulation. Entrants thus need competences and business practices in managing production and marketing under emerging economy conditions, such as strategic flexibility and networking capabilities. ${ }^{15}$ Such operational knowledge may be transferable between emerging economies, such that MNEs share experience across subsidiaries to develop unique capabilities for supporting local brand strategies. Firms with strong operational capabilities but without internationally-known brands may opt for this type of strategy (Exhibit 2).

Insert Exhibit 2 here 


\subsection{Multi-tier strategies}

Foreign entrants can combine global and local brands to achieve synergies between them. This is especially appropriate in markets that are highly segmented, as is common in emerging economies. 'Multi-tier' strategies join global and local brands and may thus solve the dilemma of either not attaining substantial market share or not capitalizing on the global brand value. ${ }^{16}$ Acquired or newly developed local brands cater to the medium or low-price segments of the market, while global brands aim at the upper end.

Synergies arise especially in distribution channels through economies of scope in local production and logistics, and may strengthen bargaining power vis-à-vis suppliers and retailers. Parallel coverage of multiple market segments may provide some protection against market fluctuations, and, the brand value of a local brand may be enhanced through its association with the global brand. For instance, Quelch points out that even Coca-Cola has launched a wide portfolio of local brands on the back of the distribution channels of its global brand. At the same time, separate branding may protect the global brand from adverse reputation effects, such as low quality of local production.

A crucial advantage of a multi-tier strategy in an emerging economy context is the ability to introduce and promote the global brand if and when the market is ready. With economic development, demand for premium brands is likely to pick up - especially for those brands already known to aspiring new consumers. The global brand may be pushed through the existing channels of the local brands, which provides a flexible set-up to react to market trends. Early movers may then earn high returns on their investment in a premium brand.

However, multi-tier strategies also carry additional costs and risks. Different market segments may require different competences and organizational cultures. This, in turn, creates operational challenges for firms aiming to integrate business units with different imperatives, such as margin versus volume, and innovation versus low cost. For example, the management of branded pharmaceuticals may require different competences than those required for generic pharmaceuticals. Moreover, an association with a weak local distribution system could weaken a global brand. This would be of particular concern for consumer durables, such as cars or televisions, for which premium customers expect a higher level of associated services. For such products, sharing retail outlets and after-sales service units for different brands may be less advisable. This is, however, of 
less concern for fast moving consumer goods, such as beer, because retail outlets and pubs usually prefer to offer a range of different brands.

A multi-tier strategy has to be supported by an appropriate combination of resources. As illustrated in Exhibit 2, firms with global brands and the capability to support this brand in remote corners of the world would choose a global strategy (quadrant I). Firms with expertise in operating and upgrading production and marketing in emerging economies but without a global brand can expand by building local brands (quadrant II). A multi-tier strategy may be most attractive in terms of market reach, yet it requires the MNE to possess crucial resources for both segments (quadrant III).

They need a global brand and the capability to market and deliver this brand with global quality standards, as well as operational capabilities for competing with local competitors familiar with the context and producing at low costs. On the other hand, if a firm has neither a global brand nor operational capabilities that are transferable to emerging economies (quadrant IV), the company may have little to gain by investing in emerging economies. A foreign entry would require it to develop a brand and capabilities 'along the way', which is a highly risky strategy.

\section{Implementation: Acquisition of Local Firms and Resources}

How can MNE build capabilities for operating in emerging economies, and compete on the basis of local brands? A crucial element in implementing an emerging economy strategy is the acquisition of resources that are controlled by local firms. Yet, take-overs of local firms are inhibited by idiosyncrasies of emerging economy contexts, including regulatory constraints and scarcity of potential acquisition targets.

Thus, decision makers have to think creatively how to design their entry strategy. They are not limited to the traditional set of entry modes -- acquisition, Greenfield or joint venture (JV) -- as much of the academic literature implicitly assumes. Many obstacles may best be overcome by customising a mode of entry to the local context, rather than opting for a second-best mode. Entrants develop idiosyncratic forms of acquisition, such as staged, multiple, indirect and Brownfield acquisitions, as well as JVs to overcome the aforementioned obstacles in emerging economies (Exhibit 3). These allow for new variations in the key dimensions discussed in the literature, namely control $^{17}$ and access to resources. ${ }^{18}$

Insert Exhibit 3 approximately here 


\subsection{Obstacles to acquisitions}

Entrants aiming to penetrate a market would look for acquisition targets with access to or control of key points in the distribution channel, and knowledge of the political and institutional framework. Firms pursuing global brand strategies would, in particular, seek access to distribution channels that allow them to control the quality of their products. In contrast, those pursuing a local brand strategy or multi-tier strategies require a fuller range of local assets, including brand names and knowledge of local consumer behaviour. Moreover, in some contexts, cooperation with a local firm may help building political goodwill. Technology of local firms may as such not attract market-seeking investors, but the ability of the workforce to learn may be important. The employees of the relatively advanced local firms may be best qualified to benefit from training and to adopt new technologies and business practices. Yet, this broad range of resources may rarely be available in a single firm, such that suitable targets are scarce.

Even if a suitable target can be identified, an acquisition may be inhibited by obstacles specific to emerging economies. The resource endowments of local firms are often poor, and their technological upgrading and organizational integration may require considerable additional investment. Moreover, the relevant capital market institutions may not be well developed, which increases the costs of evaluating, negotiating and contracting an acquisition. To overcome these obstacles, foreign investors can choose more or less ‘aggressive’ entry strategies (Exhibit 4).

\section{Insert Exhibit 4 approximately here}

\subsection{Foothold entry strategies}

Some entry modes serve primarily to establish a foothold in a market. This includes partial acquisitions and JVs, which create options for learning and for gradual expansion without a major upfront resource commitment. ${ }^{19}$ In volatile environments, the flexibility to react to positive changes in a timely manner may be an important competitive advantage. A low level of involvement provides a platform from which to expand if the business develops favourably, while at the same time the flexibility not to commit further resources if prospects turn out to be less promising remains. ${ }^{20}$ However, entrants gain only limited control and risk being left behind by more aggressive competitors committing more resources. 
Traditionally many MNEs establish a new operation jointly owned with a local firm, a JV. This provides a foothold, especially where legal constraints inhibit acquisitions, and avoids having to take responsibility for an existing local firm with major restructuring challenges. In a JV, only selected resources are transferred to the new organization, leaving the core businesses of both partners separate. However, the ownership arrangement is inherently unstable and potential conflicts between the parent companies have to be managed carefully.

Marketing and growth strategies are common areas of conflict between parents of a JV. For instance they may disagree on the relative priority of local and global brands in the marketing budget. Serious conflicts often arise when a foreign investor wishes to expand and invest in building the global brand. The local partner may be unable or unwilling to contribute fresh resources for an aggressive growth strategy, but at the same time object to capital increases that would dilute the local's equity share and influence. Thus, JVs require less commitment, but may lock the investor into a partnership that later limits growth options. Forward looking JV founders would anticipate such conflicts when drafting the JV contract, for instance by stipulating conditions under which one partner may take over the JV.

Like JVs, "staged acquisitions" require limited initial investment, yet this investment goes into an existing firm. At the outset, staged acquisitions are partial acquisitions in which the foreign investor has the option to acquire full control later. The initial role of the foreign investor varies considerably depending on the contract accompanying the entry. In the case of privatization, the investor often gains managerial control, but is subject to formal and informal constraints on radical restructuring. The investor may thus obtain access to local distribution channels but only limited control over the positioning of local brands (or their possible discontinuation). The increase of the foreign investor's equity stake may be pre-planned at the outset or be initiated in response to changes in the environment, particularly changes in FDI regulation.

Partial acquisitions are potentially subject to conflicts that require compromises among shareholders. The nature of potential conflicts varies with the identity of coowners. In contrast to JVs, they normally do not draft a contract with clearly articulated common objectives, such that conflicts are more likely. On the other hand, the buy-out of the remaining shareholders may be easier, especially if they do not have a strategic interest in the firm. 
Why do investors in emerging economies accept to share control? Often, the decision is a matter of limited opportunities, as the owner may be unwilling to sell outright. This is common for both privatisation agencies and family-owned businesses, the most frequent 'sellers' of enterprises in emerging markets. However, the continued involvement of the previous owner may also be advantageous for the acquirer. ${ }^{21}$ If the state or an influential local conglomerate shares the risks as well as the profits of the business, they may also help alleviate potential adverse interference by bureaucrats in less predictable institutional environments. Thus, shared ownership may help aligning the interests of the local community with the prosperity of the business.

\subsection{Aggressive Entry Modes}

Multiple and brownfield acquisitions allow aggressive market entries that build on more than an existing local business units, but they also require higher initial resource commitment. "Multiple acquisitions" is probably the most aggressive entry strategy. Where local firms are small, a single acquisition may not suffice to attain a strong market position, especially when targeting the mass market where economies of scale are important. Multiple acquisitions allow foreign investors to build a strong nationwide market position in traditionally fragmented markets, and to create a portfolio of local brands for multiple regional or niche markets. Consequently, an acquisition is often only a small building block in the envisaged new operation in an emerging economy.

Another aggressive mode would combine elements of acquisition and greenfield

in a "Brownfield acquisition", ${ }^{22}$ where the post-acquisition investment exceeds the investment in the original acquisition. The restructuring needs of some firms in emerging markets are so extensive that foreign investors essentially replace all resources apart from a few sought after assets, such as local brand names, licenses or distribution channels. It may appear counter-intuitive that foreign investors are willing to shoulder the burden of transforming an uncompetitive enterprise, but they would do so if the perceived value of the key assets exceeds the restructuring costs. The assets motivating brownfield acquisitions are often brands of high local esteem. By combining aspects of traditional acquisitions and Greenfield operations, Brownfield investments provide an aggressive route into a market.

Conventional acquisitions, taking over a single firm and building the local operation on that firm, are an intermediate form in terms of aggressiveness of the market entry (Exhibit 4). The same applies normally to "indirect acquisitions" that occur as a by- 
product of an acquisition in a different country. In rare cases, the operation in an emerging economy is actually the strategic asset that inspired the third-country acquisition. An indirect acquisition may be a short-cut to gaining market share quickly, especially if the acquired firm has strong global and local brands.

These entry modes provide innovative means to implement entry strategies, especially multi-tier strategies that depend on the combination of resources from the foreign investor and local partners. Entry modes set the stage for foreign investors' market position, but also shape possibilities for later fine-tuning. Foothold strategies, such as staged acquisitions and joint ventures, provide flexibility by creating growth options. Aggressive strategies using full and multiple acquisitions provide flexibility through control and, thus, the ability to change the local operation.

\section{Emerging Economies Strategy: The case of Carlsberg}

\subsection{The Global Brewing Industry}

Beer is a traditional, culturally embedded product, especially in Europe. Like other food products, it is influenced by local cultures and traditions, and the regional origin of the product plays an important role in the buyer perception. Thus, customer loyalty to local tastes and brands creates barriers to entry for international brands. Moreover, beer's short shelf life, high transport costs, as well as tariffs and national quality standards used to limit the internationalisation of the industry. ${ }^{23}$ These characteristics of the industry suggest that, traditionally, local brands would dominate in this industry (Exhibit 1).

Even so, the industry has gone through a rapid concentration and internationalisation in recent years. Local brands still dominate in most markets worldwide, yet they are often owned and supported by multinational brewers, a 'hidden globalisation'. ${ }^{24} \mathrm{~A}$ few global players emerged, expanding by acquisitions and global mergers such as Ambev-Interbrew and SAB-Miller. They combine local, global and multi-tier strategies.

A local brand strategy has been pursued most famously by South African Breweries (SAB), which expanded in the 1990s from their South African base to emerging economies in Africa, Asia, and Eastern Europe. Typically, they acquired local breweries and reorganized the production and marketing to make them profitable. SAB developed local brands to fit the markets, while at the same time increasing productivity by replicating its low-cost brewing techniques and rigorously applying standardized 
management procedures. However, global market leaders, such as Heineken and Interbrew, mostly pursue multi-tier strategies; and Carlsberg joined this trend.

\subsection{Carlsberg's global strategy}

Carlsberg participated in the global industry concentration and grew their beer business internationally while divesting its non-brewing activities. Until the 1990s, it pursued related diversification in its home market, and internationalized primarily by focusing on the two global brands, Carlsberg and Tuborg, while treating local brands as a side activity (Exhibit 2). In many emerging economies, the Carlsberg brand was brewed in JVs or under license by an independent firm, while elsewhere it was imported.

However, over the past decade, the corporate strategy has been shifted from related diversification in the home market to a strategy of 'globalfocusing' ${ }^{25}$ Carlsberg developed its core capabilities in brewing and marketing of beer to be transferable to both mature and emerging economies, while exiting secondary activities that build on different key competences. Thus, brewing activities outside Denmark grew from 38\% to $74 \%$ of turnover over the 1990s. By the turn of the millennium, Carlsberg had become one of the top five brewers worldwide, generating turnover chiefly outside its home base of Denmark. In 2004, less then 5\% of beer brewed by Carlsberg was sold in Denmark. Eastern Europe contributed $46 \%$ of beer sales by volume and $23 \%$ of revenues, while Asia contributes $9 \%$ of volume and $4 \%$ of revenues. (The discrepancies between volume and revenue data indicate the price differences between West European markets and emerging economies, but also the potential for revenue increases as incomes rise.)

A milestone in the strategic repositioning of Carlsberg was the merger with the brewing operations of Norwegian conglomerate Orkla in 2000. Orkla held a 50\%-stake in Baltic Beverage Holdings (BBH), which had developed specific competences to acquire, restructure and reposition local brands in countries of the former Soviet Union. It thus achieved strong market positions, including a 33\% market share in Russia. The merger provided Carlsberg with a wider range of human and financial resources that could support a fully developed multi-tier strategy, combining a global brand with local brands (Exhibit 2). Thus, local brands moved from being a side activity to a central part of

\section{Carlsberg's business strategy.}

Emerging economies in Europe and Asia have played a pivotal role in Carlsberg's ambition to advance from a European player to a global leader. The company entered many countries as an early, but not first, mover. Carlsberg was therefore often in the role 
of a challenger rather than an incumbent. Central and Eastern Europe provided a natural stepping stone, given its proximity to Carlsberg's home in Denmark. Major competitors entered the region, especially Poland, thus creating pressures to follow suit. Smaller economies, such as Lithuania, provided opportunities to build emerging market experience in relative cultural proximity. In Asia, Carlsberg has in invested since the early 1990s. The JVs in Vietnam were fairly successful, while those in China were insufficient to gain a strong market position. Thus, a new 'Go West' strategy was launched for China in 2003. We explore the adaptation of strategies to the diverse market structure and the institutional environment in four emerging economies (Exhibit 5).

Insert Exhibit 5 and 6 here

Carlsberg positioned the Carlsberg brand as a 'locally-brewed international premium brand' which is complemented by national premium brands: Okocim in Poland, Svyturys in Lithuania and Halida in Vietnam. Regional and niche market brands complete the product portfolios (Exhibit 6). The global premium brand 'Carlsberg' is supported by a global marketing strategy that includes TV commercials produced for use, with limited adaptation, in many emerging economies, and advertising at major international sport events. For example, sponsorship of Euro 2004 allowed Carlsberg to reach even pubs in Vietnam, where European football is very popular and fans stay up all night to follow the games. The price differences between market segments are large, as local brands are substantially cheaper than in Western Europe, while prices for premium brands vary less between countries. Top brands thus sell at a substantial premium. The Carlsberg brand may be priced with a premium over mainstream brands of $10 \%$ in Germany, $25 \%$ in Poland, and a multiple of that in China. Carlsberg combined many types of acquisition to build its market positions, moving from foothold entries to more aggressive strategies.

Insert Exhibits 7 and 8 here

\subsection{Poland}

The Polish brewing industry went through a rapid concentration process during the 1990s. In less then 15 years, a highly fragmented industry became dominated by three major players controlling over $80 \%$ of the market in 2004, with competitive dynamics increasingly resembling those seen in Western Europe (Exhibit 7). 
Carlsberg entered later than its key competitors, and combined multiple entry modes to build its multi-tier position. It established a foothold in 1996 with a 31.6\% minority stake in one of Poland's oldest breweries, Okocim (Exhibit 8). This brewery had been privatised in 1992, and Carlsberg acquired most of its shares from German brewer Brau und Brunnen, while local owners, which included many employees, were reluctant to sell. Okocim had been a leading national brewery with a $10.2 \%$ market share in 1990 , yet its market share had slipped to $8.3 \%$ by the time Carlsberg acquired an equity stake. ${ }^{26}$ It lost more market share before Carlsberg revamped the brand in 2001.

This equity stake was gradually increased until Carlsberg acquired 100\% and delisted Okocim from the stock exchange in 2004 - a staged acquisition. Even with shared control, Carlsberg obtained control over crucial aspects of the business by appointing its own people to key positions. Local media believed that shared ownership would be a long term arrangement, but at Carlsberg headquarters the aim was to eventually attain full equity control. This strategy gave Carlsberg market access and partial control, and the option to increase its equity by buying out minority shareholders.

During the first five years, Carlsberg was primarily concerned with acquiring assets, turning the operations profitable, and introducing the Carlsberg brand for the premium market. However, major acquisitions by its global competitors, Heineken and $\mathrm{SAB}$, pressured Carlsberg to become more aggressive. It needed more than Okocim to challenge them, and thus pursued a strategy of multiple acquisitions. In 2001, CarlsbergOkocim acquired two breweries, Kasztelan and Bosman, from German brewery Bitburger. In the same year, Carlsberg took over Dyland in the Netherlands, which owned the Polish brewery Piast - an indirect acquisition. In this acquisition drive, Carlsberg acquired market share and several regional brands.

Carlsberg pushed forward with integrating operations and creating a coherent brand portfolio after it had built a broad base of resources, in particular local brands, and trained staff for both production and marketing. In 2001, the portfolio was consolidated to create distinct products for different market segments. Thus, the number of local brands was reduced, while some acquired brands were replaced with new ones. Carlsberg and Okocim were positioned, respectively, as international and national premium brands, while Kasztelan, Bosman and Piast were strengthened in their specific regional markets. Moreover, Carlsberg integrated its four breweries in Poland under joint brand management. Production was reorganized to realize economies of scale, to reduce the number of production sites, and to increase productivity at the remaining plants. 
After consolidating the brand portfolio, Carlsberg launched a major branding initiative in May 2002 to reposition the Carlsberg brand. The market share was hence increased from $0.2 \%$ to $1.5 \%$, and Carlsberg overtook Heineken (1.2\%) as the leading international brand. Euromonitor analysts were impressed by this spectacular growth: "The sales of the Carlsberg brand increased by over $700 \%$ in 2002 . This growth was the result of a good promotional campaign based on a well-balanced marketing strategy, including TV commercials which consumers liked from their launch. Introducing a new disposable $500 \mathrm{ml}$ bottle also helped." 27 At the same time, the portfolio of regional brands was streamlined, while new brands such as Harnas were introduced to serve niche markets. The product portfolio thus served all major segments of a highly segmented industry and the sales strategy emphasized the full range of the Carlsberg products. Carlsberg boosted its market share to 14.2\% in 2002 (Exhibit 7). From 2004, the integration extended beyond Polish borders, as Carlsberg affiliates in different European countries began sharing production capacity.

Even though Carlsberg was a relatively late entrant into the Polish market, this multi-track strategy laid the foundation for Carlsberg to become the third largest brewer in Poland. Continuous investment, development of niche brands, and adept integration of separate operations are designed to enable Carlsberg to challenge the market leaders and to raise profitability.

*** Exhibit 9 approximately here $* * *$

\subsection{Lithuania}

Compared to Poland, Lithuania offers a much smaller market, and in consequence less regional segmentation and fewer players in the market. In consequence, Carlsberg attained a dominant market position at a much earlier stage, and thus came in conflict with the competition authorities. Also as a consequence of the smaller market size, Carlsberg's activities in Lithuania were earlier integrated in a supra-national operation covering all of the Baltic States.

Carlsberg acquired nearly full ownership of local market leader Svyturys in 1999. Around the same time, BBH acquired two breweries: Utenus Alus and Kalnapilis. The merger with Orkla, which owned 50\% of BBH, strengthened Carlsberg's position in Russia and the Baltic States (Exhibit 9). Thus, Carlsberg expanded in Lithuania as part of a global merger that extended Carlsberg's reach in the entire region. This indirect 
acquisition gave Carlsberg market leadership, but the Lithuanian competition authorities intervened because the joint market share exceeded $40 \%$. Kalnapilis was then sold, while Svyturys and Utenus Alus were integrated with BBH's operations in the Baltic States. Carlsberg was thus established as premium brand, supported by two domestic brands. The strong market position enables Carlsberg's Lithuanian affiliate to become one of the most profitable operations in emerging economies.

\subsection{Vietnam}

Vietnam has, compared to Poland or Lithuania, a much lower per capita income, with a less developed brewing industry. Thus, Vietnam displays a larger distance between the small, high margin premium market and the regionally fragmented mass market.

Carlsberg entered the market at a very early stage, by establishing two JVs with local state-owned firms in 1993. In part this entry was motivated by the availability of cofunding from the Danish investment fund IFU, as Vietnam became a priority partner for Danish development policy. The JV mode allowed for an early mover advantage in a fastgrowing industry, when regulatory constraints did not permit acquisitions and local breweries were part of state-owned conglomerates that could not realistically be taken over. Both JVs placed from the outset a strong emphasis on the development of the new local brands Halida (derived from “Halimex + Danish”) and Huda ("Hué + Danish”). The

local brands were brewed with Carlsberg technology, but adapted to local tastes, being made less bitter than European beers and suitable for consumption 'on ice'. Two global brands were introduced in the early 1990s, but the Tuborg brand was withdrawn later as local demand in the premium segment proved insufficient. The Carlsberg brand serves the small but fast growing demand in the premium segment, especially in northern Vietnam.

The local partners transferred part of their existing operations to the JV, including production lines previously built through a turnkey project with a Carlsberg affiliate. Carlsberg maintains control indirectly through its brand name, by having at least one expatriate permanently based in Hanoi, and - initially - by having a Danish financial investor as a partner. Even without majority ownership, Carlsberg engaged in major training and restructuring investments. ${ }^{28}$ After several years of losses, both JVs generated handsome profits, which were largely generated by the local brands. This experience illustrates not only the power of local brands in lower income markets, but also the need for multi-year horizons for entry strategies in emerging economies. 
In 2003, Carlsberg bought out the investment fund and increased its equity to respectively $50 \%$ and $60 \%$, while the role of the local partners in Vietnam remained unchanged. In 2005, the production capacity limits were reached, and Carlsberg considered a further expansion. A new agreement was signed with its main local competitor, Hanoi Brewery. Thus, early entry required compromises with respect to control arrangements in the local JVs, but allowed Carlsberg to build a first mover advantage and strong local brands, and to position its Carlsberg brand in the still small but growing premium segment.

\subsection{China}

China offers a much larger market than any of the aforementioned countries, yet this market is highly fragmented regionally, especially in the brewing industry. Carlsberg first entered China through exports in 1987, but it did not commit major resources until 2003. In the early 1990's Carlsberg undertook the first steps in brewing inside China (Exhibit 9). Huizhou Brewery in Guandong was licensed to brew the Carlsberg brand in 1991, and in 1995 Carlsberg acquired 99\% of the equity of the firm. It produced a local brand, Dragon 8, and by 2006 became the main base of the Carlsberg brand for all of China.

In 1998, Carlsberg opened a US\$ 80 million Greenfield brewery near Shanghai to produce premium beer. However, following continued losses over several years, Carlsberg sold its equity stake to Tsingdao, a leading brewery in the North of China, at a loss. Apparently, Carlsberg overestimated the growth of the premium segment and underestimated the pace of upgrading of local brands and the marketing savvy of international competitors in that market, such as Japanese Sapporo.

After the divestment, Carlsberg found itself in a relative late-comer position in the Chinese market, as the Guandong operation was strong only in the local market. In many costal areas, the brewing industry was becoming highly competitive as local breweries and global players rapidly consolidated. By the turn of the millennium, the potential for late entrants was limited.

Carlsberg thus designed a new strategy that build on its experience across emerging economies. Its 'go West' strategy aims to establish market positions by acquiring equity stakes in the Western provinces of China. Carlsberg identified and systematically penetrated these ‘virgin territories' of the global beer industry. In 2003-4, Carlsberg acquired equity stakes in five breweries from Kunming in Yunnnan province to Wusu in Xinjiang province, and established a JV in Qinghai province, which lacked a 
strong local brewery. By way of multiple acquisitions, Carlsberg thus acquired over 50 local brands, including two nationally known brands, Huanghe (Yellow River) and Lhasa. The branding strategy for Western China thus focuses on local brands that at some point in the future may be complemented by the Carlsberg brand. In the coastal regions, Carlsberg pushes the global brand, brewed in Guandong, and a newly created 'Carlsberg Chill' brand that targets younger consumers and the nightlife scene in the big cities.

The market shares in some of the Western provinces are quite impressive, in particular in Xinjiang (95\%) and Ningxia (80\%). However, these provinces are only slowly catching up with the economic growth of China, and per capita beer consumption is well below the national average of 22 litres. Thus, Carlsberg's new China strategy has a long time horizon, and the partial acquisitions may well turn into staged acquisitions. However, it is too early to comment on the success of this strategy.

\section{Discussion}

Market positioning and entry strategies are important for success in emerging economies, and they have to reflect the opportunities and challenges in the specific local context. Markets are often fragmented, with major differences in volumes and margins between global and local brands. Many MNEs focus on their global brands, while others, like $\mathrm{SAB}$, focus on managing operations efficiently under emerging market conditions and with local brands. As Prahalad argues, such a strategy requires not only the development of local brands, but also business concepts that fit the context. We have argued that investors can combine local and global strategies, but they need to develop appropriate operational capabilities for the specific local context. The Carlsberg case illustrates that such a strategy is complex and needs to be implemented over long time horizons.

The optimal combination of local and global brands depends on the firm's resources and capabilities (Exhibit 2). MNEs with global brand recognition and the organizational capabilities to support the brand in far-flung places may perform best with a global brand strategy. Firms with operational knowledge in building brands and managing production in emerging economies may be best served by developing a portfolio of local brands.

A multi-tier positioning is a more ambitious strategy that may to lead to long-term market leadership. Yet, it requires both a global brand and local operational capabilities. Synergies may be realized by sharing of distribution networks, and by investing in the global brand in anticipation of rising demand. The Carlsberg case illustrated how multi- 
tier branding allows to profitably develop the mass market while creating strong positions in the growing middle-class-oriented premium market.

To build a market position, foreign investors need complementary context-specific resources that can be obtained through a JV or by acquiring a local firm. The appropriate design (rather than choice) of entry mode is crucial to capture local resources without losing control over one's own resources or being drawn into a complex enterprise transformation processes. Moreover, the entry strategy needs to allow for strategic adjustments and increases of resource commitments to adapt to environmental change. As emerging economies tend to be highly volatile, competitive advantages may accrue to those best able to adapt to changing circumstances. This flexibility can be achieved in different ways. A staged acquisition or JV provides opportunities to accelerate investment if and when market opportunities arise. More aggressive modes such as full or multiple acquisitions require more up-front resources, but provide full control over the operations, and thus the ability to flexibly change the business strategy.

The Carlsberg case illustrates the innovative ways by which foreign investors arrange their acquisitions to overcome the obstacles to acquisitions in emerging economies. Carlsberg accelerated its investment from initially low or moderate commitment. The partial acquisitions (Poland) and JVs (Vietnam) provided footholds, and were making the best use of available resources and acquisition opportunities, at the time. However, shared ownership creates major challenges for knowledge transfer and deep restructuring, and for coordinating strategic changes with the local partners.

In its drive to establish strong market positions, Carlsberg added substantial investments to the initial operation. The combination of different modes and flexible adjustment of the strategy facilitated access to crucial market assets, especially brand names and distribution networks. Although Carlsberg often missed the opportunity to be the first in a new market, it succeeded in establishing strong market position as number 3 in Poland, number 2 in Vietnam, and number 1 in Lithuania and some provinces of China.

In transferring lessons from Carlsberg's experience to other industries, however, readers should recall that brewing is a culturally embedded industry with high degrees of loyalty to local brands. Other consumer goods, for instance technology-driven appliances such as digital cameras or I-pods, may experience much faster global convergence as innovations in Asia diffuse to Europe in a few months. In such industries, global brands dominate while local brands have, at best, a supportive role, and required local assets 
relate primarily to sales outlets and after-sales service. The relevance of local assets and the motives to acquire local firms, thus vary considerable across industries.

\section{Conclusions}

Our paper offers a number of insights for mangers designing or implementing an emerging economy strategy. Our Exhibits are hoped to help managers to analyze key issues for market penetration and acquisition strategies:

- Foreign investors may position themselves in the premium segment, the mass market, or combine both in a multi-tier strategy (Exhibit 1). The latter may often be most promising in terms of the long term market position, yet it needs to be supported by a combination of global brands and operational capabilities for the specific local context (Exhibit 2).

- Foreign investors need to design (not select) an appropriate entry mode that provides access to local resources needed to support the chosen entry strategy. The optimal mode would vary with the aggressiveness and thus resource commitment that the investor would want to pursue (Exhibit 4). Moreover, the range of the available modes is wide (Exhibit 3), and decision makers should adopt and combine what suits best to their local industry structure, consumer behaviour and the institutional environment.

The paper also raises a number of questions for further research. Many of our suggestions are based on qualitative case research, which may be further deepened by quantitative research investigating the relationships proposed. In the area of marketing, it would be interesting to explore which resources are transferable across borders, and thus influence firms' design of product portfolios (Exhibit 2)? Moreover, how can MNE optimally balance investment in premium and mass market brands when pursuing multi-tier strategies (Exhibit 1)?

In entry strategy research, scholars may investigate what resource needs and environmental constraints specifically determine acquirers' choice of acquisition strategy in terms of our differentiated terminology (Exhibit 3). Moreover, how do these alternative strategies affect the risk profile, strategic flexibilities, organizational rigidities and financial performance of the new operation (Exhibit 4). Finally, our analysis points to the 
need to integrate research streams on marketing and entry modes, and to analyze the interdependencies between these two aspects of entry strategy.

\section{Appendix: Research Methods}

This paper draws on insight gained from two major research projects on foreign direct investment in respectively Vietnam, India, Egypt and South Africa, and in Hungary, Poland and Lithuania. In the context of this research, authors based in the respective countries prepared a total of 21 case studies from 2002 to 2004. These case studies focus on foreign investors' entry strategies and the design of entry modes. In contrast to most studies that use interviews at headquarters as the primary source, our research draws extensively on local sources, including interviews and archival data. The results of the first project have been published in the aforementioned book by Estrin and Meyer, while the latter are forthcoming in a new book on acquisitions in European emerging economies. ${ }^{29}$ This research led to the main conceptual developments in this paper.

As part of these research projects, the case of Carlsberg was investigated in Poland, Lithuania and Vietnam. It serves here to illustrate the variation of business strategy across different contexts. Starting with the country case studies that focus on entry strategies and have been prepared by respectively T.H. Nguyen, H.V. Nguyen and C.N. $\operatorname{Tran}^{30}$ by M. Bak ${ }^{31}$ and by V. Darskuvenie (unpublished), we have conducted additional archival research and interviews at both corporate headquarters, with industry experts and with Carlsberg's CEO in Vietnam, focusing especially on marketing. The case of China is based on interviews with industry experts as well as archival materials, including publications by Carlsberg. The presentation of the case thus combines archival data, commissioned case studies, and the authors' own interviews. The information has been triangulated across these different sources, and the final draft of this paper has been discussed with Carlsberg executives. 
Exhibit 1: Where to use which strategy?

\section{Global Brand Strategy}

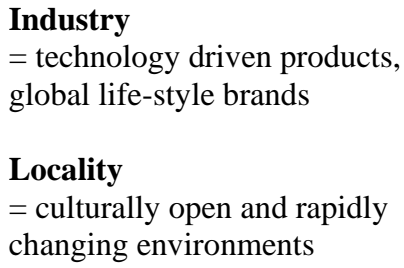

Core competences

$=$ product and brand based competences
Local Brand Strategy

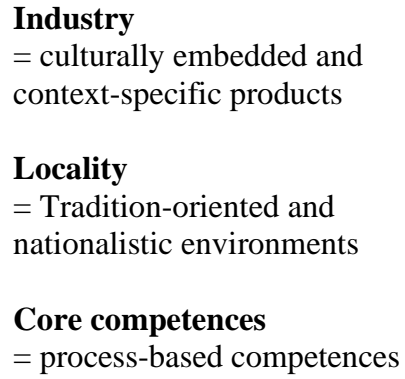

= culturally embedded and context-specific products

Locality

$=$ Tradition-oriented and nationalistic environments

Core competences

$=$ process-based competences

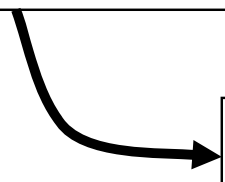

Multi-Tier Strategy

Industry

$=$ segmented industries

(especially mass market vs. premium segment)

Locality

= highly segmented locations

(e.g. urban vs. rural markets)

Core competences

= product/brand and process

based competences

\section{Exhibit 2: Branding Strategies}

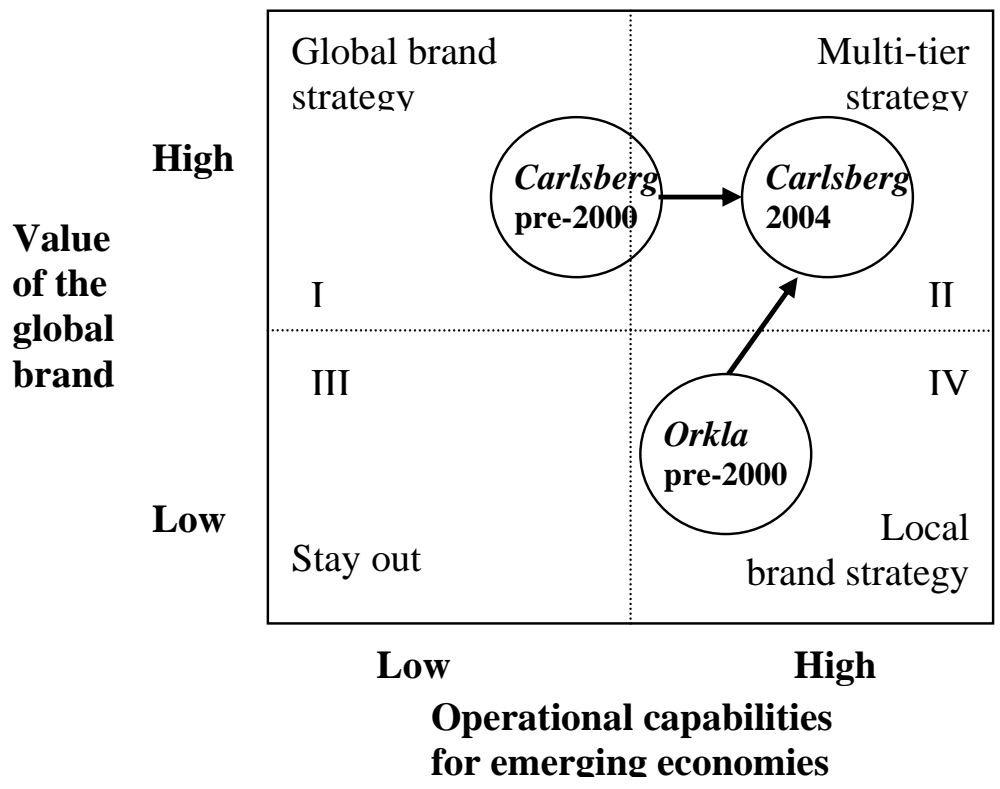




\begin{tabular}{|c|c|c|c|c|}
\hline \multicolumn{3}{|r|}{ Description } & \multicolumn{2}{|c|}{ Purpose } \\
\hline $\begin{array}{l}\text { Staged } \\
\text { acquisition }\end{array}$ & \multicolumn{2}{|c|}{$\begin{array}{l}\text { Initially acquiring only an equity stake, } \\
\text { and gradually increasing equity to } 100 \% \text {, } \\
\text { possibly over several years. }\end{array}$} & \multicolumn{2}{|c|}{$\begin{array}{l}\text { Continued involvement of previous owners } \\
\text { that are unwilling to sell outright, or needed } \\
\text { to maintain legitimacy with local } \\
\text { stakeholders. }\end{array}$} \\
\hline $\begin{array}{l}\text { Multiple } \\
\text { acquisition }\end{array}$ & \multicolumn{2}{|c|}{$\begin{array}{l}\text { Acquiring several independent } \\
\text { businesses, and subsequently integrating } \\
\text { them. }\end{array}$} & \multicolumn{2}{|c|}{$\begin{array}{l}\text { Build a strong market position in a } \\
\text { traditionally fragmented market. }\end{array}$} \\
\hline $\begin{array}{l}\text { Indirect } \\
\text { acquisition }\end{array}$ & \multicolumn{2}{|c|}{$\begin{array}{l}\text { An acquisition outside the focal country } \\
\text { with an affiliate in the same emerging } \\
\text { economy. }\end{array}$} & \multicolumn{2}{|c|}{$\begin{array}{l}\text { The prime objective may be outside the } \\
\text { country. The affiliate may motivate the } \\
\text { acquisition, but this is rare. }\end{array}$} \\
\hline $\begin{array}{l}\text { Brownfield } \\
\text { acquisition }\end{array}$ & \multicolumn{2}{|c|}{$\begin{array}{l}\text { An acquisition in which the foreign } \\
\text { investor subsequently invests more } \\
\text { resources in the operation, such that it } \\
\text { almost resembles a Greenfield project. }\end{array}$} & \multicolumn{2}{|c|}{$\begin{array}{l}\text { Access to crucial local assets under control } \\
\text { of local firms that are in many other ways } \\
\text { not competitive. }\end{array}$} \\
\hline Joint venture & \multicolumn{2}{|c|}{$\begin{array}{l}\text { A new company in which two or more } \\
\text { parents share ownership. }\end{array}$} & \multicolumn{2}{|c|}{$\begin{array}{l}\text { Accessing local resources without taking } \\
\text { responsibility for an existing company. }\end{array}$} \\
\hline \multicolumn{5}{|c|}{ Exhibit 4: Market Penetration Strategies } \\
\hline & & $\begin{array}{l}\text { Foothold } \\
\text { Strategies }\end{array}$ & $\longrightarrow$ & $\begin{array}{r}\text { Aggressive market } \\
\text { leadership strategies }\end{array}$ \\
\hline Examples & & $\begin{array}{l}\text { - Partial / staged } \\
\text { acquisition } \\
\text { - Joint Venture }\end{array}$ & $\begin{array}{l}\text { - Conventional (full) } \\
\text { acquisition } \\
\text { - Indirect acquisition }\end{array}$ & $\begin{array}{l}\text { - Multiple acquisition } \\
\text { - Brownfield } \\
\text { acquisition }\end{array}$ \\
\hline \multicolumn{2}{|c|}{ Resource commitment } & $\begin{array}{l}\text { Initially low or } \\
\text { moderate }\end{array}$ & High & Very high \\
\hline \multirow{2}{*}{\multicolumn{2}{|c|}{$\begin{array}{l}\text { Control } \\
\text { Required knowledge of } \\
\quad \text { local context }\end{array}$}} & Low & High & High \\
\hline & & Low & Moderate & High \\
\hline \multicolumn{2}{|c|}{ Speed of entry } & Low & Moderate & High \\
\hline \multicolumn{2}{|l|}{ Sources of risk } & $\begin{array}{l}\text { Risk of being too slow, } \\
\text { limited control over } \\
\text { brand portfolio. }\end{array}$ & $\begin{array}{l}\text { Moderate degrees of all } \\
\text { sources of risk }\end{array}$ & $\begin{array}{l}\text { Capital investment risk } \\
\text { (high costs of exit) }\end{array}$ \\
\hline \multicolumn{2}{|c|}{ Sources of flexibility } & $\begin{array}{l}\text { Low initial sunk costs } \\
\text { allow choosing } \\
\text { alternative paths of } \\
\text { growth later, or exit. }\end{array}$ & $\begin{array}{l}\text { High control allows } \\
\text { changing the } \\
\text { organization in a top- } \\
\text { down manner. }\end{array}$ & $\begin{array}{l}\text { High control allows } \\
\text { changing the } \\
\text { organization in a top- } \\
\text { down manner. }\end{array}$ \\
\hline \multicolumn{2}{|c|}{ Sources of rigidity } & $\begin{array}{l}\text { Lock in contracts and } \\
\text { relationships may } \\
\text { limit growth options }\end{array}$ & $\begin{array}{l}\text { Existing organizational } \\
\text { structures may not fit } \\
\text { the entrants business } \\
\text { practices }\end{array}$ & $\begin{array}{l}\text { Combination of firms and } \\
\text { aggressive } \\
\text { restructuring may } \\
\text { overcome rigidities in } \\
\text { conventional } \\
\text { acquisitions }\end{array}$ \\
\hline
\end{tabular}


Exhibit 5: Beer Markets in four Emerging Economies

\begin{tabular}{|c|c|c|c|c|c|}
\hline & & \multicolumn{2}{|c|}{ Poland } & Lithuania & Vietnam \\
\hline \multicolumn{2}{|c|}{$\begin{array}{l}\text { Population (million, } \\
\quad 1990 \rightarrow \text { 2003) }\end{array}$} & \multicolumn{2}{|c|}{$38.2 \rightarrow 38.5$} & $3.6 \rightarrow 3.5$ & $66.2 \rightarrow 80.9$ \\
\hline \multicolumn{2}{|c|}{$\begin{array}{l}\text { GDP p.c. (US\$ } 1990 \\
\quad \rightarrow \text { 2003) }\end{array}$} & \multicolumn{2}{|c|}{$4,267 \rightarrow 5,487$} & n.a. $\rightarrow 4,028$ & $98 \rightarrow 471$ \\
\hline \multicolumn{2}{|c|}{$\begin{array}{l}\text { p.c. beer consumption } \\
\quad \text { (litre, } 1999 \rightarrow \text { 2003) }\end{array}$} & \multicolumn{2}{|c|}{$52 \rightarrow 68$} & $54 \rightarrow 78$ & $8 \rightarrow 12$ \\
\hline \multicolumn{2}{|c|}{ Consumer taste } & \multicolumn{2}{|c|}{$\begin{array}{l}\text { Long beer tradition, lager } \\
\text { and dark beers, } 25 \% \\
\text { strong beers (over } 7 \% \\
\text { alcohol). Beer replacing } \\
\text { liquor and vodka. }\end{array}$} & $\begin{array}{l}\text { Long beer tradition, } \\
\text { lager and dark beers. } \\
\text { Beer replacing liquor } \\
\text { and vodka. }\end{array}$ & $\begin{array}{l}\text { Little beer tradition, } \\
\text { preference for light beers. } \\
\text { Beer as part of new } \\
\text { lifestyle and } \\
\text { accompaniment to meals. }\end{array}$ \\
\hline \multicolumn{2}{|c|}{ Consumption patterns } & \multicolumn{2}{|c|}{$40 \%$ off-site trade. } & $\begin{array}{l}\text { Mainly off-site trade, } \\
80 \% \text { sales to retail } \\
\text { chains. }\end{array}$ & $\begin{array}{l}\text { High share of on-site } \\
\text { consumption, especially } \\
\text { in the premium segment. }\end{array}$ \\
\hline \multicolumn{2}{|c|}{ Industry structure } & \multicolumn{2}{|c|}{$\begin{array}{l}\text { Initially highly } \\
\text { fragmented, rapidly } \\
\text { concentrating. }\end{array}$} & $\begin{array}{l}\text { Initially oligopolistic, } \\
\text { increased concentration. }\end{array}$ & $\begin{array}{l}\text { Highly fragmented, slow } \\
\text { concentration process. }\end{array}$ \\
\hline \multicolumn{2}{|c|}{ FDI Regulation } & \multicolumn{2}{|c|}{$\begin{array}{l}\text { Ownership restrictions } \\
\text { rapidly phased out; } \\
\text { privatisation often with } \\
\text { employees as minority } \\
\text { shareholders. }\end{array}$} & $\begin{array}{l}\text { Ownership restrictions } \\
\text { rapidly phased out; } \\
\text { privatisation often to } \\
\text { insiders of the firm. }\end{array}$ & $\begin{array}{l}\text { Ownership restrictions } \\
\text { required } \mathrm{JV} \text {, relaxed only } \\
\text { in the late } 1990 \text { s; little } \\
\text { privatisation. }\end{array}$ \\
\hline \multirow{2}{*}{\multicolumn{6}{|c|}{$\begin{array}{l}\text { Sources for Exhibit 5: Euromoney (2004), case materials. Per capita consumption data are averaged from a } \\
\text { variety of source reporting different estimates. }\end{array}$}} \\
\hline & & & & & \\
\hline \multirow[b]{3}{*}{ Poland } & \multirow{2}{*}{\multicolumn{2}{|c|}{$\begin{array}{l}\text { International } \\
\text { premium brands } \\
\text { Mostly brewed in } \\
\text { the country }\end{array}$}} & \multicolumn{2}{|c|}{$\begin{array}{l}\text { National } \\
\text { premium brands }\end{array}$} & Niche market brands \\
\hline & & & Mostly acquil & $\begin{array}{l}\text { Mostly } \\
\text { acquired }\end{array}$ & $\begin{array}{l}\text { Mostly newly created, } \\
\text { e.g. 'nightlife' market }\end{array}$ \\
\hline & Carlsberg & & Okocim & $\begin{array}{l}\text { Bosman } \\
\text { Kasztelan } \\
\text { Piast } \\
\text { Ksiaz }\end{array}$ & $\begin{array}{l}\text { Karmi } \\
\text { Volt } \\
\text { Harnas }\end{array}$ \\
\hline Lithuania & \multicolumn{2}{|l|}{$\begin{array}{l}\text { Carlsberg } \\
\text { Baltica 1) }\end{array}$} & $\begin{array}{l}\text { Svyturys } \\
\text { Utenos Alus }\end{array}$ & --- & --- \\
\hline Vietnam & \multicolumn{2}{|l|}{$\begin{array}{l}\text { Carlsberg } \\
\text { Tuborg 2) }\end{array}$} & Halida 3) & $\begin{array}{l}\text { Huda 3) } \\
\text { Festival 3) }\end{array}$ & --- \\
\hline China & \multicolumn{2}{|c|}{ Carlsberg } & $\begin{array}{l}\text { Huang He 4) } \\
\text { Lhasa 4) }\end{array}$ & $\begin{array}{l}\text { Ca } 50 \text { local } \\
\text { brands }\end{array}$ & Carlsberg Chill \\
\hline
\end{tabular}

Notes: 1) Regional brand for Russia and the Baltic States, 2) initially introduced, but discontinued, 3) developed jointly with the local JV partner, 4) Nationally known brands. 
Exhibit 7: Market Shares in Poland, in per cent

\begin{tabular}{|c|c|c|c|c|}
\hline By brand owner & 1996 & 2000 & 2001 & 2002 \\
\hline Heineken (Netherlands) & 10.4 & 31.4 & 31.3 & 32.7 \\
\hline SAB (South Africa) & 11.1 & 29.5 & 30.6 & 31.5 \\
\hline Carlsberg (Denmark) & 8.3 & 7.5 & 12.1 & 14.2 \\
\hline Browary Szczecin (local) & 2.0 & *) 3.0 & --- & --- \\
\hline Browary Piast (local) & 4.2 & *) 1.1 & --- & --- \\
\hline Others & 64.0 & 27.5 & 26.0 & 21.6 \\
\hline By brand (Carlsberg brands) & & 2000 & 2001 & 2002 \\
\hline Okocim & & 4.9 & 5.4 & 4.9 \\
\hline Okocim Premium / Okocim Jasne Pelne & & 1.4 & 1.3 & 0.9 \\
\hline Okocim Porter & & 0.1 & 0.1 & 0.1 \\
\hline Carlsberg & & 0.2 & 0.2 & 1.5 \\
\hline Kastelan & & *) 1.8 & 1.8 & 1.9 \\
\hline Bosman & & *) 1.2 & 1.2 & 1.2 \\
\hline Piast & & *) 1.1 & 1.1 & 1.1 \\
\hline Karmi & & 0.3 & 0.4 & 0.3 \\
\hline By brand (key competitors) & & 2000 & 2001 & 2002 \\
\hline Tyskie Gronie (SAB) & & 14.9 & 16.7 & 19.0 \\
\hline Zywiec (Heineken) & & 12.4 & 12.5 & 12.9 \\
\hline Lech (SAB) & & 6.2 & 6.0 & 6.0 \\
\hline Tatra (Heineken) & & 1.9 & 3.6 & 5.3 \\
\hline Heineken (Heineken) & & 1.0 & 1.1 & 1.2 \\
\hline
\end{tabular}

Sources: 1996: Górzynski (2002) Graph 2.6 and Table 2.3; 2002-2002: Euromonitor (2004).

Notes: *) acquired by Carlsberg in 2001.

Exhibit 8: Timeline for Carlsberg in Poland

\begin{tabular}{|c|c|c|c|c|}
\hline & \multicolumn{4}{|c|}{ Poland } \\
\hline & Okocim & Kasztelan & Bosman & Piast \\
\hline $\begin{array}{l}\text { Early } \\
1990 s\end{array}$ & $\mathrm{SOE}$ & SOE & $\mathrm{SOE}$ & $\mathrm{SOE}$ \\
\hline 1992 & Privatised by partial IPO & & & \\
\hline \multicolumn{5}{|l|}{1993} \\
\hline 1994 & $\begin{array}{l}\text { Brau \& Brunnen (Germany) } \\
\text { acquired } 25 \% \text { from the state }\end{array}$ & & $\begin{array}{l}\text { Privatised to } \\
\text { individual investor }\end{array}$ & \\
\hline 1996 & $\begin{array}{l}\text { Carlsberg acquired 31.6\%, } \\
\text { Brau \& Brunnen exits }\end{array}$ & Privatised & $\begin{array}{l}\text { Individual investor } \\
\text { sold to Bitburger }\end{array}$ & $\begin{array}{l}\text { Privatised to individual } \\
\text { investor }\end{array}$ \\
\hline 1997 & $\begin{array}{l}\text { Carlsberg brand brewed in } \\
\text { Poland }\end{array}$ & & & \\
\hline \multicolumn{5}{|c|}{ 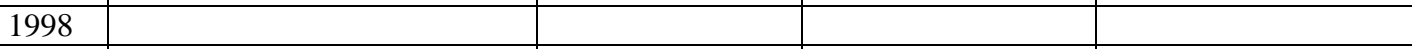 } \\
\hline 1999 & & $\begin{array}{l}\text { Bitburger } \\
\text { acquired } 99.39 \%\end{array}$ & & \\
\hline 2000 & & \multicolumn{2}{|c|}{ Merged in Browary Szczecin } & Dyland bought $98 \%$ \\
\hline 2001 & $\begin{array}{l}\text { Carlsberg increased equity } \\
\text { stake to } 50.1 \% \text {, followed by } \\
\text { public offer }\end{array}$ & \multicolumn{2}{|c|}{$\begin{array}{l}\text { Carlsberg Okocim acquires ownership } \\
\text { from Bitburger }\end{array}$} & $\begin{array}{l}\text { Carlsberg bought } \\
\text { Dyland }\end{array}$ \\
\hline 2002 & \multicolumn{3}{|c|}{$\begin{array}{l}\text { Carlsberg increased equity stake to } 71.4 \% \text {. Start of operational } \\
\text { integration. }\end{array}$} & \\
\hline 2003 & \multicolumn{3}{|l|}{ Increase of equity stake to $75 \%$. } & Operational \\
\hline 2004 & \multicolumn{3}{|c|}{$\begin{array}{l}\text { Call for buying outstanding shares and withdrawal from Warsaw Stock } \\
\text { Exchange. Pan-European operational integration and production } \\
\text { capacity sharing. }\end{array}$} & $\begin{array}{l}\text { integration of } \\
\text { separate legal entity. }\end{array}$ \\
\hline
\end{tabular}


Exhibit 9: Timeline for Carlsberg in Lithuania, Vietnam and China

\section{Lithuania}

1997 First negotiations with Svyturys, with no results

1999 Carlsberg acquires 97.6\% in Svyturys, BBH acquires Utenos Alus and Kalnapilis

2001 Following the Carlsberg-Orkla merger, Carlsberg sells Syvturys to its new affiliate BBH. The competition authorities intervene, Kalnapilis is sold.

2002 Svyturys and Utenos Alus are organizationally integrated with BBH operations across the Baltic states.

\section{Vietnam}

Ca 1990 Six turnkey projects with different breweries in Vietnam

1993 Establishment of two JV in respectively Hanoi and Hue, with financial participation of investment fund IFU

2003 Acquisition of the equity stake of IFU in both JV

2004 New JV for distribution operations, with same partner in Hanoi

2005 Collaboration agreement with local competitor Hanoi Brewery

\section{China}

1991 Start of production of Carlsberg brand in Huizhou Brewery, Guandong

1995 Acquisition of Huizhou Brewery in Guandong

1998 Greenfield plant in Shanghai starts operations

2000 Sale of $75 \%$ equity stake in Shanghai plant to Tsingdao.

2003 Initiation of West-China strategy, full acquisition of Kunming Huashi Brewery and Dali Brewery

2004 Investment in Lhasa Brewery (33\% equity), Lanzhou Huanghe Group (30\%), Xinjian Wusu Brewery (50\%) and a joint venture in Qinghai province (33\%).

2005 Letter of intent for acquisition of Ningxia Xixia Brewery. Sale of remaining 25\% stake in Shanghai plant. 


\section{References:}

${ }^{1}$ D. J. Arnold and J. A. Quelch, New Strategies in Emerging Markets, Sloan Management Review, Fall, 7-20 (1998).

${ }^{2}$ C.K. Prahalad, The Fortune at the Bottom of the Pyramid: Eradicating Poverty Through Profits, Prentice Hall (2004).

${ }^{3}$ S. Estrin and K.E. Meyer (Eds.), Investment Strategies in Emerging Economies, Cheltenham: Elgar (2004).

${ }^{4}$ C.K. Prahalad and L. H. Stuart, The Fortune at the Bottom of the Pyramid, Strategy + Business, Booz Allen Hamilton, (26), 1-14, (2002).

${ }^{5}$ N. Dawar and A. Chattopadhay, Rethinking Marketing Programs for Emerging Markets, Long Range Planning 35: 457-474 (2002).

${ }^{6}$ A.K. Kozminski \& G. Yip (Eds.), Strategies for Eastern Europe, MacMillan 2000.

${ }^{7}$ R. Batra, Marketing Issues and Challenges in Transition Economies, Journal of International Marketing 5 (4), 95-114 (1997).

${ }^{8}$ K. Uhlenbruck, K.E. Meyer, and M. Hitt, Organizational transformation in transition economies: Resource-based and organizational learning perspectives, Journal of Management Studies (40), 257-282 (2003).

${ }^{9}$ J.P. Doh and R. Ramamurti, Reassessing Risk in Developing Country Infrastructure, Long Range Planning 36: 337-353 (2003).

${ }^{10}$ T. Khanna, K.G. Palepu and J. Sinha, Strategies that Fit Emerging Markets, Harvard Business Review, May-June, 83-89 (2005).

${ }^{11}$ J.A. Quelch, Global Brands: Taking Stock, Business Strategy Review 10: 1-14.

${ }^{12}$ M.T.T. Nguyen: An investigation into conspicuous consumption in a transitional economy: A study of emerging urban consumers in Vietnam, unpublished PhD Thesis, Department of Marketing, National University of Singapore (2003).

${ }^{13}$ D.A. Aaker and E. Joachimthaler, The Lure of Global Branding, Harvard Business Review, November-December 1999, 137-144.

${ }^{14} \mathrm{~T}$. London and S.L. Hart, Reinventing strategies for emerging markets: beyond the transnational model, Journal of International Business Studies 35: 350-370 (2004).

${ }^{15}$ C.J. Kock and M.F. Guillén, Strategy and Structure in Developing Countries: Business Groups as an Evolutionary Response to Opportunities for Unrelated Diversification. Industrial and Corporate Change: 10: 77-113 (2000).

${ }^{16}$ A. Schuh, Global standardization as a success formula for marketing in Central Eastern Europe? Journal of World Business, 133-148 (2000).

${ }^{17}$ E. Anderson and H. Gatignon, Modes of foreign entry: A transaction cost analysis and propositions, Journal of International Business Studies 17 (Fall): 1-26 (1986).

${ }^{18} \mathrm{~J}$. Anand and A. Delios, Absolute and relative resources as determinants of international acquisitions, Strategic Management Journal 23, 119-134 (2002).

${ }^{19}$ M.W. Peng: Business Strategies in Transition Economies, Thousand Oaks, CA: Sage (2000).

${ }^{20}$ B. Kogut and N. Kulatilaka, Option Thinking and Platform Investment: Investing Opportunities, California Management Review, Winter, 52-71 (1994).

${ }^{21}$ K.E. Meyer, Management Challenges in Privatization Acquisitions in Transition Economies, Journal of World Business 37 (4), 266-276 (2002).

${ }^{22}$ K.E. Meyer and S. Estrin, Brownfield Entry in Emerging Markets, Journal of International Business Studies, 31 (3), 575-584 (2001).

${ }^{23}$ R. Benson-Armer, J. Leibowitz and D. Ramachandran, Global beer, what's on tap? The McKinsey Quarterly, Number 1 (1999).

${ }^{24}$ A. Schuh, Globalization as diffusion process: An analysis of the dissemination of Western brands in Central and Eastern Europe, EIBA conference, Copenhagen, December (2003).

${ }^{25}$ K.E. Meyer, Globalfocusing: From Domestic Conglomerate to Global Specialist, Journal of Management Studies, forthcoming in 2006.

${ }^{26}$ M. Górzynski, Consolidation of ownership and market consolidation: The role of relational investors in the Polish beer market 1990-1999, working paper no. 11, School of Slavonic and East European Studies, London (2002). 
${ }^{27}$ Euromoney, Alcoholic Drinks in Poland, mimeo (February 2004).

${ }^{28}$ H.T. Nguyen and K.E. Meyer, Managing partnerships with state-owned joint venture companies: Experiences from Vietnam, Business Strategy Review 15 (1), 39-50 (2004).

${ }^{29}$ K.E. Meyer and S. Estrin, eds: Acquisition Strategies in European Emerging Economies, Basingstoke: Palgrave-MacMillan, forthcoming in 2006.

${ }^{30}$ T.H. Nguyen, H.V. Nguyen and C.N. Tran: Vietnamese Case Studies, in S. Estrin and K.E. Meyer (Eds.), Investment Strategies in Emerging Economies, Cheltenham: Elgar (2004).

${ }^{31}$ M. Bak, Carlsberg Breweries A/S in Poland: Growth through Multiple Acquisitions, in: K.E. Meyer and S. Estrin, eds. (2006): Acquisition Strategies in European Emerging Economies Basingstoke: Palgrave-Macmillan, forthcoming in 2006. 